\title{
A Probe into Cultivation of Intercultural Communication Competence in Business English Learning
}

\author{
Wu Chunrong ${ }^{1}$ \\ ${ }^{1}$ School of Foreign Languages, Sichuan University of Science \& Engineering, China \\ Correspondence: School of Foreign Languages, Sichuan University of Science \& Engineering, Xueyuan Road No. \\ 180, Zigong City, Sichuan Province, China, 643000. Tel: 86-138-9000-9729. E-mail: 363493649@qq.com
}

Received: September 16, $2015 \quad$ Accepted: September 28, $2015 \quad$ Online Published: October 29, 2015

doi:10.5430/ijelt.v3n1p56 URL: http://dx.doi.org/10.5430/ijelt.v3n1p56

\begin{abstract}
This paper starts with an introduction of the importance of the current need for the development of intercultural communication competence. That is, with the development of global economy, intercultural communication becomes increasingly significant and frequent today. China, as a member of WTO, gets involved in more communications with other countries. More talents who have a good command of English knowledge and intercultural communication competence are in great need for China. Thus students majoring in Business English are faced with both great opportunities and challenges. They should not only understand what is culture and intercultural communication, but also master intercultural communication strategies and improve intercultural communication competence in their study. Armed with these essential competences, they can overcome culture barriers and reduce culture conflicts on international business occasions. This paper introduces the definition of culture and intercultural communication and comes up with three suggested ways to foster Chinese learners to develop their intercultural communication competence in Business English learning. It analyzes the importance and necessity of business communication from a global perspective, aiming to help the Business English learners to strengthen the awareness of intercultural communication, cultivate the strategies of intercultural communication and improve their communication competence.
\end{abstract}

Keywords: culture, intercultural communication competence, Business English

\section{Introduction}

In the $21^{\text {st }}$ century, with the development of global economy, people are becoming increasingly interconnected with the whole world, and need to understand the people whose background is quite different from their own. To communicate effectively with people from different cultures needs to cultivate people's intercultural communication competence.

In China, however, traditional teaching-mode of Business English focuses on students' listening, speaking, reading and writing skills rather than intercultural communication competence. A lot of students may wonder why they should cultivate communication competence. For students majoring in Business English, they are supposed to realize that living in a global village and facing the multi-cultural societies, to interact with people from different cultures is an issue to face with. So they cannot ignore the necessity of cultivating intercultural communication competence, and there seems a must to grasp some basic intercultural communication competence to catch up with the trend of globalization.

The lack of intercultural awareness is a common problem in the cultivation of intercultural communication competence, which would lead to misunderstandings of other cultures. That is to say, without the cultivation of intercultural awareness, to cultivate intercultural communication competence becomes a mission impossible. Thus, the urgent need for students majoring in Business English is to improve their intercultural awareness and cultivate their intercultural communication competence in Business English Learning.

Therefore, this paper tries to probe into the cultivation strategies of intercultural communication competence in Business English learning in order to arouse students' intercultural awareness and help them to seek some practical approaches to improve their intercultural communication competence in Business English learning. 


\section{The Background of Intercultural Communication}

\subsection{The Definition of Culture}

For the definition of culture, there have been many versions. Kroeber and Kluckhohn(1952), for example, cites 164 definitions in the anthropology literature, ranging from all-encompassing ones to narrower ones ( "it is everything"; "it is opera, art, and ballet". Hoebel and Frost (1976) say culture is an "integrated system of learned behavior patterns which are characteristic of the members of a society and which are not the result of biological inheritance." We hold Samovari's explanation of culture is encompassing(1998): culture is the deposit of knowledge, experience, beliefs, values, actions, attitudes, meanings, hierarchies, religion, notions of time, roles, spatial relations, concepts of the universe, and artifacts acquired by a group of people in the course of generations through individual and group striving. Culture includes everything from rites of passage to concepts of the soul.

Language, as one of the most important tools in intercultural communication, is an evolved cultural pattern and cultural carrier as well. Different languages always reflect different culture backgrounds. To put it in other words, Chinese share comparatively the same culture with the people who are native speakers of Chinese language, while English-speaking people don't. When encountering with Westerners, the first problem is how to communicate with them. With modern society highly developed, no one can deny that people are more and more frequently participating in intercultural communication. To begin with, the definition of intercultural communication needs to be clarified.

\subsection{The Definition of Intercultural Communication}

Wikipedia defines intercultural communication (also frequently referred to as cross-cultural communication, which is also used in a different sense, though) as "a field of study that looks at how people from different cultural backgrounds communicate, in similar and different ways among themselves, and how they endeavor to communicate across cultures."

The communicative behavior of an individual is greatly influenced by culture. Through the process of socialization, individuals acquire distinct beliefs, values and norms. And all of these cultural patterns can be conveyed through the process of communication. So when students are learning the course of Business English or participating in intercultural communication, they can easily find that our original reactions, attitudes and feelings are not the same as what have been described in the text books.

\section{Intercultural Communication in Business English Learning}

\subsection{The Background of Business English}

Business English is the name given to the English used for dealing with business communication in English (Talbot, 2009). With the purpose of developing business relationship with the company from the English-speaking countries, many non-native English speakers study Business English with the goal of doing business with the United States or other English-speaking countries. A particularly interesting fact is that there are more non-native speakers of English than native English speakers. The UK government estimates that more than one billion people speak English, and projections indicate that by 2020 two billion people throughout the world will be learning or teaching English (Talbot, 2009). As known to all, the world of business is developing at an amazing speed. So it is essential to communicate in a major language of commercial communication - English. Nowadays English does not only belong to the nation that firstly uses this language, but also functions as a communicative tool which crosses borders and cultures.

There is an intimate connection between language and culture. Language is both the carrier and a raw portrayal of culture (Hu, 1999). Culture has great influence on the development and use of vocabulary, the rules of grammar, the structure of the articles and so on. English language learners share growing realization that mastering the pronunciations, vocabulary and grammar of English, without understanding of the culture cannot improve their competence and performance in Business English rapidly. That is to say, intercultural communication competence is absolutely essential in English learning, especially in Business English learning.

The "indoctrination" is the most commonly-used method in traditional English teaching in China. As the main body of the whole class, teachers often read the words, the sentences and the text. Students are just in passive positions to do the reading practice, and read after teachers again and again. This teaching mode is so teacher-centered that students have few opportunities to show themselves. So they are not active learners, but passive ones. That's why the atmosphere of class is not active but boring. And more importantly, for students majoring in Business English, that's definitely not the way that can make them communicate more smoothly with the native speakers in authentic 
business situations.

\subsection{The Necessity of Cultivating Intercultural Communication Competence in Business English Learning}

Business English learning is not just a subject of language study, instead, it offers an access to learn the concepts of western business management. So Business English learners not only take Basic English ability as measurement of Business English learning, and the fact is that the competence of intercultural communication is more essential indeed, for John Corbett states that intercultural communicative competence includes the ability to understand the language and behavior of the target community, and explain it to members of the "home" community-and vice versa (Corbett, 2000). What's more, Business English learners shall learn the way to encounter with westerners in the field of international business. It is necessary to adapt themselves to the professional way and style of the international business. Thus, there is a must to figure out why Business English learners should cultivate intercultural communication competence in Business English learning.

\subsubsection{An Inevitable Requirement of Economic Globalization}

In the process of economic globalization, China, the biggest developing country in the world, also catches up with the trend of the fast development of international trade, and becomes the most important country that specializes in the final step of production: putting components together before exporting them to the final users. So in this supply chains, Chinese import and export companies need to encounter with the foreign companies. On the stage of international trade, graduates with essential intercultural communication competence are in great demand. As a result, there is no substitute for students of Business English Major to strengthen the learning of intercultural communication competence. That is to say, China is an inevitable member of economic globalization, while intercultural communication competence is an inevitable requirement for Business English learners.

\subsubsection{A Need for a Bridge over Culture Barriers}

Participating in intercultural communication, people are most likely to mistakenly think the one from different culture backgrounds would have the same reaction as theirs. Eventually when they find that his or her reaction is totally different from what they have expected, it will just turn out to be such a disappointing and unsuccessful case of intercultural communication.

\section{Case:}

Zhang Yi is working at a foreign trade company, who has been invited to a party hosted by his foreign client Eric. It is his first time to attend such a formal occasion. He wears a smart suit, and gets to the party on time. But when he arrives, he finds there are few acquaintances; the only one he knows is his client Eric. After greeting with him, Eric just introduces him to some other foreigners, but he has little communication with them. Zhang Yi feels it very strange that Eric does not talk with him again at the party. Finally, he makes up some excuse and leaves for home.

For Zhang $\mathrm{Yi}$, it is an unsuccessful experience of intercultural communication. The reason why he fails to communicate with those people at the party is that he thinks it is a good chance to communicate with his client Eric. Meanwhile, he ignores the opportunity to associate with other potential friends and clients at the party. Because what he expects is just typical perspective from a Chinese. He has his expectation of how to be treated at the party, but the result turns out to be definitely far away from his expectation. As foreigners are educated in different culture backgrounds, their attitudes and ways to people or situations are not the same as ours. Due to the lack of intercultural communication experience, he fails to communicate with foreigners. And Zhang Yi's built-in thought becomes the major barriers in his intercultural communication.

Cultural differences between China and western countries are the most troublesome difficulties in Business English learning. It is quite obvious that the best way to overcome these culture barriers is to acquire some basic intercultural communication skills during the learning of Business English, especially for the people whose work will be related to the international business. In the process of international business, no one can predict whether you are meeting an overseas client, negotiating a deal, or giving an important presentation, the use of English is necessary, and also intercultural communication competence is a necessity as well. Basically, students majoring in Business English, who are armed with intercultural communication competence, can benefit a lot. At least, they will get along well with their overseas clients in the future, and avoid culture conflicts to the most extent.

\section{The Cultivation Strategies of Intercultural Communication Competence in Business English Learning}

Business English aims at the efficient ways to communicate with English-speaking people on business occasions. In Business English learning, intercultural communication skills are based on the intercultural competence, which refers 
to those attitudes, knowledge, behaviors, and practices that enable individuals to interact effectively and meaningfully with others whose backgrounds are different from their own. It includes intercultural attitudes, intercultural knowledge, intercultural skills and critical cultural awareness. In order to cultivate intercultural communication competence, one should have an insight into the practical and useful cultivation strategy.

\subsection{To Cultivate Intercultural Awareness}

As mentioned above, we have already realized the necessity of intercultural communication competence. It is, however, far from the awareness of the necessity. During the learning of Business English, learners' only focus on the language study and the outline of International Trade cannot enlarge their extension of knowledge. Namely, students majoring in Business English are supposed to feel obliged to cultivate intercultural awareness.

Cultural awareness, according to Chen and Starosta (Chen \& Starosta, 1997), refers to an understanding of one's own and others' cultures that affect how people think and behave, which includes understanding commonalities of human behavior and differences in cultural patterns. Thus intercultural awareness is helpful to have a more objective view when there are different styles of thinking patterns. It is definitely incorrect to say one's style or pattern is right or wrong, as each has its feature as well as uniqueness.

The cultivation of students' intercultural awareness can help them have a better understanding of the target language. Suggested approaches to cultivate students' intercultural awareness hereby will be discussed as follows.

\subsubsection{To Compare Cultural Differences}

In order to communicate with foreigners, both native and foreign culture must be brought together to interact. Students' intercultural awareness can be aroused by comparing the cultural differences between the native and target language. So it is quite meaningful to know the culture differences, such as, culture differences between China and western countries, the different business etiquettes etc..

For instance, westerners are very strict with their agendas, especially the Europeans. They are always making appointments before they do something, such as a meeting, a medical examination and even a haircut. The principles of timing are rather strict in their beliefs. Most of Chinese, however, do not make appointments for such things. By comparing these differences in the principles of timing, students' intercultural awareness is enhanced. So when they communicate with westerners, especially do business with them, this kind of cultural differences shall be highly valued. And they will be less likely to expect the westerners react in the same way as Chinese do, moreover, they will do it in the way the westerners prefer to. Students ought to learn more about the native and foreign culture, customs and even preferences, and extensively compare them to cultivate students' intercultural awareness. As a result, when students interact with westerners, they will have a better communication with them, avoiding cultural barriers efficiently.

\subsubsection{To Develop Different Thinking Patterns}

With the great help of the comparisons between different cultures, students' intercultural awareness starts to be aroused. The second advisable step to cultivate intercultural awareness is to focus on the development of different thinking patterns, which means the process of "putting yourself into someone else's shoes".

There is no doubt that thinking patterns have a great influence on the ways of speaking. Take the different thinking patterns of Americans and Chinese as an example - Americans tend to speak in a straightforward way, while Chinese prefers an indirect way. In order to avoid obstacles in intercultural communication, Chinese ought to directly focus on the point, when talking to foreigners.

By developing different thinking patterns, intercultural awareness can be promoted. For students can be aware that people from different culture backgrounds will have different perspectives.

\subsection{To Develop Culture-oriented Courses in Business English Learning}

Chinese College English Syllabus (1999) specifies the teaching objectives as follows:

College English teaching is designed to help students develop a relatively strong reading ability and their general skills at listening, speaking, writing and translation, so that they are able to use English to communicate. College English is intended to help students lay a solid foundation of language skills, master good language learning strategies, foster their culture quality, and adapt them to the requirements of the social development and economic construction (Xu, 2008).

So it is easily found that there is no clear statement of the goal or the requirements of culture teaching in the syllabus of College English. Mostly, culture teaching is treated as an accompanying course to help students clear away the 
barriers in understanding a language. The necessity of learning the culture of the target language in Business English learning is so important that it is far from adequate to integrate culture in some courses. Thus students are supposed to learn some culture-oriented courses which help students accumulate more foreign culture knowledge, including western customs, history, geography, politics, economy and other aspects.

Take eating habits for example, when westerners eat together, they pay more attention to personal space, on the contrary, we Chinese like to sit around a large table, eating and chatting a lot. This is a lively reflection of two different customs of get-together. These different customs are owing to the different cultural backgrounds. Westerners pay much attention to their personal space, and they tend to individualism. While in China, people are collectivists. We believe that happiness shall be shared and we prefer to do things together, especially, especially on some important occasions.

The more western cultural knowledge students heap up, the better understanding of it they will have, which could be of great help to cultivate intercultural communication awareness and develop intercultural communication skills.

\subsection{To Take Advantages of On-line Materials}

The best way to learn Business English is to learn something from the people's practice. With the rapid development of modern information technology, Internet has become a nice assistant for students' Business English learning. Various kinds of information on the Internet could be one of the most useful resources for Business English learning. More foreign films and TV programs are available on the Internet to deepen the understanding of the exotic culture to make up for the deficiency in opportunities of real intercultural communication.

Take the film The Treatment Guasha for example, it vividly shows great culture differences between China and America. There is one scene in the film that Paul ran to his mom and told her that Dennis beat him. And then Datong asked Dennis to apologize to Paul. But when Dennis refused to do so, Datong beat him in the face of other people. Quinlan was quite surprised at what Datong did to Dennis, and said: "Kids fight and make it up. Just let it go! ” Then Datong's father quoted an old Chinese proverb "you may admonish your children in front of others, and your wife, only in privacy."

It shows that Chinese and American parents hold totally different attitudes to disciplining kids. In traditional Chinese culture, beating and punishments are commonly used to discipline their children. Most Chinese parents believe that beating and punishments are good methods to give children a lesson and make them keep it in mind what is supposed to do and what is not supposed to do, while American parents can hardly accept these ideas. They prefer children's self-discipline, and they believe that even making mistakes may help children to somehow figure out how to solve problems by themselves in the future.

By analyzing the cultural differences in this film, students could know better of the characteristics of intercultural communication, and make improvement in their intercultural communication competence.

Taking advantages of numerous on-line materials can widen the horizon and cultivate intercultural communication competence. For students majoring in Business English, it is really a good opportunity to cultivate intercultural communication competence with the help of modern IT.

\section{Conclusion}

Since language is closely related to culture, students should attach great importance to the cultivation of intercultural communication competence. By analyzing the backgrounds of culture, intercultural communication and Business English, students could have a better understanding of why they should cultivate intercultural communication competence. For students majoring in Business English, the necessity of intercultural communication competence is self-evident to all, so that they cannot hesitate to arouse their intercultural awareness, and Business English teachers should guide them to pay attention to intercultural awareness, instead of learning English simply to pass the TEM-4 and TEM-8. Only mastering the related knowledge of Business English and western culture, can they overcome the culture barriers and reduce culture conflicts in the real international business situations.

\section{References}

Chen, D. M., \& Starosta, W. J. (1997). A Review of the Concept of Intercultural Sensitivity. Human Communication, $1,1-16$.

Corbett John. (2000). An Intercultural Approach to English Language Teaching. Bristol: Multilingual Matters Ltd. 
Hoebel, E. A., \& Frost, E. L. (1976). Culture and Social Anthropology. New York: McMraw-Hill.

$\mathrm{Hu}$ Wenzhong. (1999). A Introduction to Intercultural Communication. Beijing: Foreign Language Teaching \& Research Publishing House.

Kroeber, \& Kluckhohn. (1952). Culture: A Critical Review of Concepts and Definitions. Harvard University.

Samour, L. A., \& Porter, .R. E. (1988). International Communication: A Reader. Wadsworth Publishing Company.

Talbot Fiona. (2009). How to Write Effective Business English. London: Kogan Page Limited.

Xu Keqiang. (2008). The Cultivation of Cross-cultural Awareness in College English Teaching. Southwest University. 